\title{
Electricity generation from wastewaters with starch as carbon source using a mediatorless microbial fuel cell
}

\author{
E. Herrero-Hernandez ${ }^{\text {a,*, }}$, T.J. Smith ${ }^{\text {b }}$, R. Akid ${ }^{c}$ \\ ${ }^{a}$ Materials \& Engineering Research Institute, Sheffield Hallam University, Howard Street, Sheffield S1 1WB, UK \\ ${ }^{\mathrm{b}}$ Biomedical Research Centre, Sheffield Hallam University, Howard Street, Sheffield S1 1WB, UK \\ c School of Materials, University of Manchester, Manchester M13 9PL, UK
}

\section{A R T I C L E I N F O}

\section{Article history:}

Received 10 May 2012

Received in revised form

17 July 2012

Accepted 20 July 2012

Available online 27 July 2012

Keywords:

Microbial fuel cells

Mediatorless

E. coli

Potato starch

Wastewater

\begin{abstract}
A B S T R A C T
Microbial fuel cells represent a new method for producing electricity from the oxidation of organic matter. A mediatorless microbial fuel cell was developed using Escherichia coli as the active bacterial component with synthetic wastewater of potato extract as the energy source. The two-chamber fuel cell, with a relation of volume between anode and cathode chamber of $8: 1$, was operated in batch mode. The response was similar to that obtained when glucose was used as the carbon source. The performance characteristics of the fuel cell were evaluated with two different anode and cathode shapes, platinised titanium strip or mesh; the highest maximum power density $\left(502 \mathrm{~mW} \mathrm{~m}^{-2}\right)$ was achieved in the microbial fuel cell with mesh electrodes. In addition to electricity generation, the MFC exhibited efficient treatment of wastewater so that significant reduction of initial oxygen demand of wastewater by $61 \%$ was observed. These results demonstrate that potato starch can be used for power generation in a mediatorless microbial fuel cell with high removal efficiency of chemical oxygen demand.
\end{abstract}

(c) 2012 Elsevier B.V. All rights reserved.

\section{Introduction}

Increasing difficulties with sustained supplies of petroleum energy sources and parallel problems of pollution and global warming that are associated with fossil fuels are a major impetus for development of renewable energy technologies. Production of electricity from renewable organic matter via microbial fuel cells (MFCs) has been explored since the 1960s; however, it is only in the last decade that the power output achieved from such MFCs has approached a level that makes them feasible for small-scale applications (Mano and Heller, 2003; Shantaram et al., 2005).

MFCs are bio-electrochemical transducers that generally comprise two compartments: an anoxic chamber containing the anode and an aerobic compartment that houses the cathode. Electrons are liberated at the anode when bacteria oxidise organic material to yield protons and carbon dioxide under anoxic conditions. The electrons pass via an external circuit to the cathode, where they combine with electron acceptors such as oxygen from air, which can combine with protons that diffuse from the anode chamber, through a cation exchange membrane; the resulting product is water. Most experimental MFCs use

\footnotetext{
* Corresponding author. Present address: Department of Procesos de Degradación del Medio Ambiente y su Recuperación, Institute of Natural Resources and Agrobiology, 37008 Salamanca, Spain. Tel./fax: +34 923219606.

E-mail address: eliseo.herrero@irnasa.csic.es (E. Herrero-Hernandez).
}

chemical oxidisers, such as ferricyanide, or permanganate (You et al., 2006) as electron acceptors in the cathode chamber, which must be replaced or regenerated. Bacteria, such as Thiobacillus ferrooxidans (Prasad et al., 2006), can also be used in the cathode chamber.

MFCs are classified into two types according to how electrons are transferred from the bacteria to the anode. In mediator-based MFCs electroactive metabolites, or 'mediators', are added to the system in relatively high concentrations to transfer electrons between the microorganisms and the electrode, in order to increase the proportion of available electrons that are transferred. Mediators may be synthetic (e.g. neutral red, methylene blue) or natural (e.g. sulphate/sulphide), depending on the species of microorganism used (Park and Zeikus, 2000; Ieropoulos et al., 2005). The alternative type of MFC is mediatorless and functions without exogenous electron carriers. Most mediatorless MFCs that have been described to date rely on metal-reducing bacteria such as Shewanella (Kim et al., 2002; Bond and Lovely, 2003; Ringeisen et al., 2006), Rhodoferax (Chaudhuri and Lovely, 2003) and Geobacteraceae (Shantaram et al., 2005; Prasad et al., 2006), which transfer electrons directly to the anode via redox enzymes in their outer membrane.

Escherichia coli is frequently utilised as a catalyst for the electrochemical oxidation of glucose to construct biosensors and mediator-based MFCs. Several types of MFCs employing glucose as the energy source and $E$. coli as the catalyst have been 
documented (Park and Zeikus, 2000; Ito et al., 2002; Park and Zeikus, 2003). However, there are few articles in which this reaction is carried in a mediatorless fuel cell and in most such cases the amount of electricity generated was substantially less than that obtained from mediator-based MFCs (Grzebyk and Pozniak, 2005; Wang et al., 2007; Alferov et al., 2009).

Microorganisms are, in principle, ideal catalysts for deriving electrical energy from a wide range of renewable sources. They are self-regenerating systems that can derive electrical energy from a gamut of chemical sources, spanning simple carbohydrates, such as glucose, sucrose, alcohols (Kim et al., 2007; Catal et al., 2008), grape juice (Liu and Dong, 2007), or complex carbon sources such as wastewaters from different origins (VelasquezOrta et al., 2011) as starch (Gil et al., 2003; Lu et al., 2009), beer brewery (Wen et al., 2009), chocolate industry (Patil et al., 2009), food processing (Oh and Logan, 2005) and sewage sludge (Jiang et al., 2009); wastes from food industry have been also used as the carbon source in MFCs (Cercado-Quezada et al., 2010).

The aim of this work was to optimise the output of a mediatorless microbial fuel cell using $E$. coli as the biocatalyst and to develop this type of fuel cell for production of electricity from potato extract, with a view to developing an MFC to derive energy from the wastewater produced by potato-processing factories.

\section{Experimental}

\subsection{Bacterial culture conditions}

The bacterial strain $E$. coli INV $\alpha \mathrm{F}^{\prime}$ (Invitrogen) was used throughout this study and was grown aerobically at $37^{\circ} \mathrm{C}$ except where stated otherwise. The bacteria were first grown on LB agar plates for $24 \mathrm{~h}$, and then stored at $4{ }^{\circ} \mathrm{C}$. Cell suspensions for use as starter cultures in MFC experiments were produced by growing the $E$. coli in $5 \mathrm{~mL}$ aliquots of buffered LB broth (tryptone, $10 \mathrm{~g} \mathrm{~L}^{-1}$; yeast extract, $5 \mathrm{~g} \mathrm{~L}^{-1}$; $\mathrm{NaCl}, 5 \mathrm{~g} \mathrm{~L}^{-1}$; Na-phosphate buffer $0.05 \mathrm{M}, \mathrm{pH} 7.2$ ).

\subsection{Microbial fuel cell construction and operation}

The microbial fuel cell was constructed according to a novel design as follows. A flask ( $1 \mathrm{~L}$ capacity) was used as the anode chamber, and the cathode chamber was a cylinder of Perspex (capacity of $125 \mathrm{~mL}$ ) with two end pieces, one of them with a hole was fixed to the anode chamber. Both chambers were physically separated by a proton exchange membrane (Nafion ${ }^{\circledR} 117$, Dupont Co.) with an interchange surface of $7 \mathrm{~cm}^{2}$. Each chamber contained a platinised titanium electrode in either strip or mesh form (Ti-shop, UK). The total accessible geometrical surface of the electrodes was $6.5 \mathrm{~cm}^{2}$. The electrodes were attached to the external system using copper wire with all exposed surfaces sealed with non-conducting silicone.

The anode chamber was loaded with an overnight liquid starter culture of bacteria $(5 \mathrm{~mL})$ and $500 \mathrm{~mL}$ of freshly autoclaved buffered LB broth, or modified M9 minimal medium $\left(\mathrm{Na}_{2} \mathrm{HPO}_{4}\right.$, $42 \mathrm{mM} ; \mathrm{KH}_{2} \mathrm{PO}_{4}, 24 \mathrm{mM}$; $\mathrm{NaCl}, 9 \mathrm{mM} ; \mathrm{NH}_{4} \mathrm{Cl}, 19 \mathrm{mM} ; \mathrm{MgSO}_{4}$, $1 \mathrm{mM}, \mathrm{CaCl}_{2}, 0.1 \mathrm{mM}$, thiamine, $0.5 \mathrm{mg} \mathrm{L}^{-1}$, with different amount of starch extracted from potatoes instead of glucose). The protocol to extract nutrients for the bacteria was devised to be similar to procedures employed in potato processing factories. Potatoes (washed and chopped, $400 \mathrm{~g}$ ) were boiled in $500 \mathrm{~mL}$ of water for one hour; the large particulate matter was removed by filtration and the extract was sterilised by autoclaving before addition to the bacterial growth medium. The potato extract used in these experiments contained $1.16 \mathrm{~g}$ of starch residue per $100 \mathrm{~mL}$ of extract. When necessary, additional carbon source was added during the experiment in the form of $15 \mathrm{~mL}$ of glucose solution $(40 \mathrm{w} / \mathrm{v} \%)$. The cathode chamber was loaded with potassium hexacyanoferrate(III) solution $0.050 \mathrm{M}$. Nitrogen and air (flow rate $20 \mathrm{~mL} \mathrm{~min}^{-1}$ ) were continuously purged through the anode and cathode compartments, respectively, to maintain anaerobic and aerobic conditions. The fuel cell was immersed in a thermostatically controlled water bath at $37^{\circ} \mathrm{C}$.

\subsection{Data acquisition and calculations}

The fuel cell was continuously monitored using a digital multimeter Mastech MAS-343, connected to a computer via an RS232C cable (Mastech Enterprise Co., China). The circuit was operated under a fixed external load resistance $\left(R_{\text {load }}\right)$ of $10 \mathrm{k} \Omega$ except where stated otherwise. The current (I) in amperes (A) was calculated using Ohm's law, $I=V / R_{\text {load, }}$, where $V$ is the potential drop in volts $(\mathrm{V})$ across the external load resistor $\left(R_{\text {load }}\right)$ in Ohms $(\Omega)$. To calculate the power output $P$ in watts $(\mathrm{W}) P=I \times V$ or the power density $P D\left(\mathrm{~W} \mathrm{~m}^{-2}\right) P D=I \times V / A$, where $A\left(\mathrm{~m}^{2}\right)$ is the area of the anode, various resistances were set using a variable resistor box (RS Components, UK).

The Coulombic efficiency (CE) was calculated using the ratio of total Coulombs obtained in the experiment $\left(C_{\mathrm{P}}\right)$ to the theoretical amount $\left(C_{\mathrm{T}}\right)$ available from complete substrate oxidation (Wen et al., 2009) $\mathrm{CE}=C_{\mathrm{P}} / C_{\mathrm{T}} \times 100 \%=(I \times t) /(F \times n \times \Delta \mathrm{COD} \times V) \times M$, where $I$ represents the current (A); $t$ is the time interval (s); $F$ is the Faraday constant $=96,485 \mathrm{C} / \mathrm{mol} ; n$ is the number of moles of electrons produced per mol of substrate; $V$ is the volume of anolyte (L); $\mathrm{M}$ is molecular weight of the substrate. Chemical Oxygen Demand (COD) was measured according to the standard method (APHA, 1998).

Biomass was estimated by taking culture samples from the fuel cell at various times and measuring the optical density at $600 \mathrm{~nm}$ with a LKB Ultrospec II spectrophotometer (LKB Biochrom Ltd., England).

\subsection{Fluorescence microscopy}

Bacteria attached to the electrode surface were imaged using fluorescence microscopy. The electrode was removed from anode chamber, rinsed with ultrapure water and stained with ethidium bromide $\left(10 \mu \mathrm{g} \mathrm{mL}^{-1}\right)$ for $5 \mathrm{~min}$ immediately prior to imaging. Samples were viewed with an Olympus BX60 fluorescence microscope operating in reflected light fluorescence mode and fitted with a U-MWG filter cube giving green excitation (Olympus, CA, USA).

\section{Results and discussion}

\subsection{Extended performance of the microbial fuel cell under an external resistance}

Once it had been established that the $E$. coli-based mediatorless MFC could be used to generate an electrical current, the performance of the MFC was monitored during prolonged operation using buffered LB medium as the nutrient source and platinised titanium strip electrodes. The cell was operated over an external load resistance of $10 \mathrm{k} \Omega$. The potential difference across the external resistance (Fig. 1) reached a maximum of more than $700 \mathrm{mV}$ approximately $6 \mathrm{~h}$ after the start of the experiment, falling to about $30 \%$ of its maximum value after a further $5 \mathrm{~h}$. Addition of extra nutrients ( $15 \mathrm{~mL}$ of $40 \%$ glucose added as indicated by the first arrow) restored the potential to the maximum value, showing that the decline in current had been due to an exhaustion of nutrients in the medium. After the potential had subsequently 


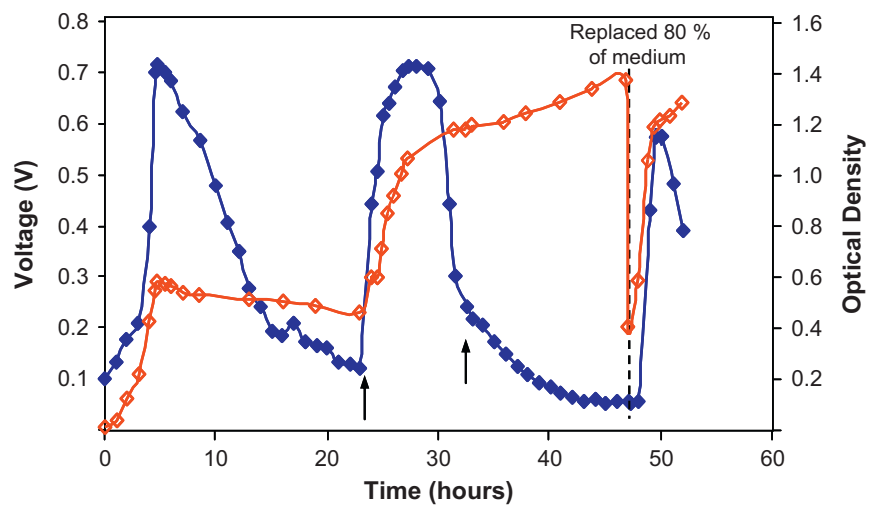

Fig. 1. Evolution of the voltage drop across an external resistance of $10 \mathrm{k} \Omega$ over an extended time ( $\mathbf{a})$. Evolution of optical density of anode solution measured at $600 \mathrm{~nm}(\square)$. Arrows indicate additions of $15 \mathrm{~mL}$ aliquots of $40 \mathrm{w} / \mathrm{v} \%$ glucose solution and dashed line indicates replacement of $80 \%$ of the bacterial culture with fresh buffered LB medium. Experiments were carried out with platinised titanium strip electrodes.

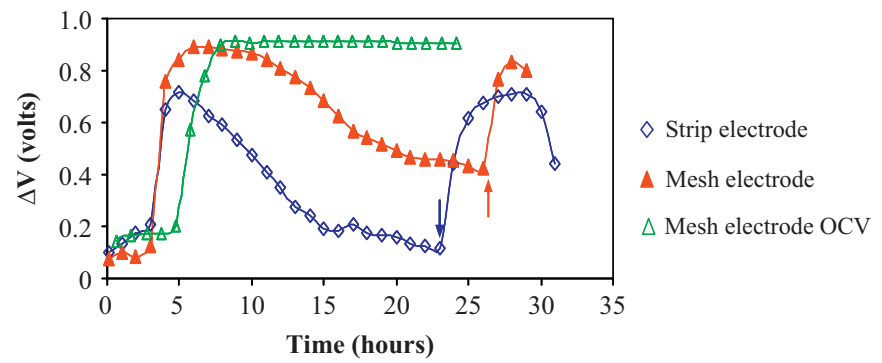

Fig. 2. Performance of the MFC over an extended time with two titanium platinised electrode configurations over an external resistance and in open circuit mode, using buffered LB as the nutrient source. Arrows indicate the point at which glucose was added to the medium in each experiment.

fallen again, another addition of the same amount of glucose did not produce any further increase in the potential. It was reasoned that this was due to the metabolic inhibition of the cells due to a build-up of acid or other toxic by-products from bacterial activity, which resulted in a drop in $\mathrm{pH}$ from 7.2 to 4.8 during the experiment. This hypothesis proved to be correct because, when $80 \%$ of the volume of the culture was replaced by fresh medium, an increase in potential difference was again observed. The three periods of high electrical output corresponded to the periods of maximum growth rate, as indicated by the observed rapid increase in optical density (Fig. 1).

\subsection{Influence of electrode configuration}

In order to investigate whether the surface structure of the electrode could be changed so as to increase the output of the MFC, experiments were conducted to compare the platinised titanium strip electrodes with alternative electrodes in which the platinised titanium was in the form of a mesh (accessible surface, $6.5 \mathrm{~cm}^{2}$ ). As in the previous experiment, the anode chamber contained an E. coli culture in buffered LB medium. When platinised titanium strip electrodes were used, the maximum voltage attained across the $10 \mathrm{k} \Omega$ external resistance was approximately $750 \mathrm{mV}$, even when glucose is added (Fig. 2). When the mesh electrodes were used the maximum voltage reached was $900 \mathrm{mV}$, indicating that there is a significant influence of the configuration and/or surface area of the electrodes on cell output. When the cell was operated with this configuration in open circuit mode, the potential began to increase after $5 \mathrm{~h}$ and reached the maximum potential over $900 \mathrm{mV}$ over a further $3 \mathrm{~h}$ period. The potential then remained constant at this maximum value until the end of the experiment. This potential in open circuit mode is essentially due to chemical changes in the anode chamber.

Corresponding polarisation curves (Fig. 3) were obtained by varying the external resistance from 0.1 to $100 \mathrm{k} \Omega$. The highest maximum power density $\left(502 \mathrm{~mW} \mathrm{~m}^{-2}\right.$, at a current of $0.90 \mathrm{~mA}$ ) was achieved using the MFC with titanium platinised mesh electrodes. This is almost one order of magnitude greater than the maximum power density of $66 \mathrm{~mW} \mathrm{~m}^{-2}$ at $0.089 \mathrm{~mA}$ obtained when strip electrodes were used. The power density measured is more than one order of magnitude greater than the maximum power density typical ( $40 \mathrm{~mW} \mathrm{~m}^{-2}$ ) of this type of two-chamber mediatorless MFC using a Shewanella putrifaciens culture and carbon electrodes (Kim et al., 2007). Electrode material and electrode design are known substantially to influence MFC output (Logan et al., 2006) and so it may be the use of electrodes from the catalytically active material platinum that permits high output in the current MFC.

\subsection{Development of the MFC to generate electricity from potato starch}

Crude starch extract from potatoes was chosen as a model system for developing the fuel cell to generate electricity using waste material from the food processing industry. With this purpose the anode chamber of the MFC was charged with an E. coli starter culture and $500 \mathrm{~mL}$ of a sterile M9 minimum medium in which glucose was replaced by a synthetic potato extract, as described in Section 2.2. Platinised titanium mesh

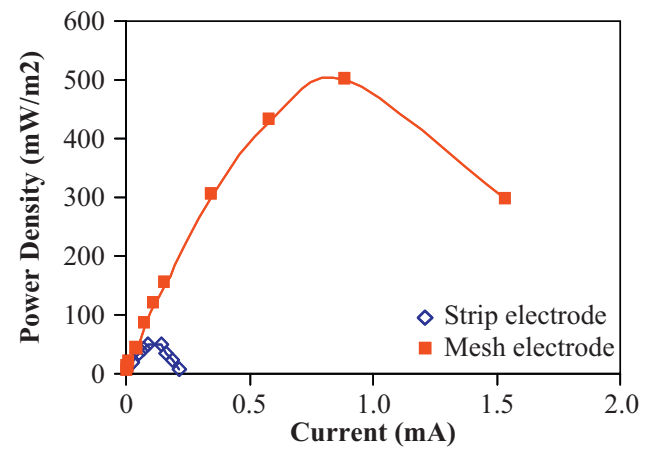

Fig. 3. Polarisation curves showing the effect of different titanium platinised electrode configurations on the power density outputs of the MFC containing E. coli and buffered LB medium at $37^{\circ} \mathrm{C}$.

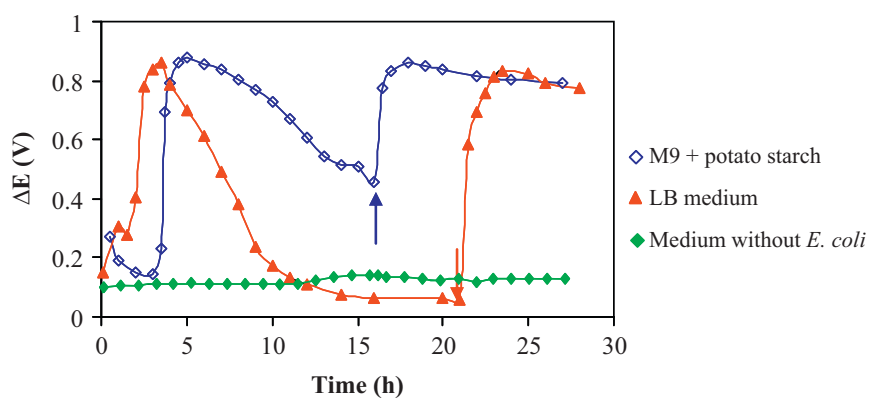

Fig. 4. Performance of the MFC using potato extract with titanium platinised mesh electrodes. The output of the cell was compared using two nutrient sources, minimal medium plus potato extract and buffered LB medium. The negative control shows minimal medium plus potato extract with no added bacteria. Arrows indicate the introduction of additional aliquots of potato extract and glucose, respectively. 
electrodes were used in both chambers and the voltage drop across the $10 \mathrm{k} \Omega$ external resistance was recorded as a function of time (Fig. 4). The maximum voltage registered was close to $900 \mathrm{mV}$, which was essentially identical to the voltage observed when buffered LB was used as the medium. After the output of the cell had declined, the behaviour of the MFC upon introduction of additional potato extract (Fig. 4) is similar to the effect of adding glucose to the MFC containing LB medium (as in Fig. 1). This result demonstrates that the mediatorless MFC utilising $E$. coli as the biocatalyst is effective in generating electricity from crude preparations of potato extract, of a kind that may be produced as waste in the potato processing industry. Also two control experiments were carried out, without addition of $E$. coli (Fig. 4), and without addition of carbon source (data not shown), in both cases no increment on voltage was registered.

Several mechanisms have been described for electron transfer between cells and the anode in MFCs. In certain electrogenic bacteria such as Rhodoferax ferrireducens, Shewanella putrefaciens, Geobacter sulfurreducens and Hansenula anomala membrane-associated c-type cytochromes are able to transfer electrons to solid substrates such as electrodes (Ramanavicius and Ramanaviciene, 2009). However, such a mechanism has not been observed in E. coli. Compounds secreted by the cells may act as electron transfer mediators, and such a process may be facilitated if the cells form a biofilm on the electrode surface. Fig. 5 shows a microscopic photograph of electrode surface where the $E$. coli cells can be seen densely attached on the electrode surface, consistent with biofilm formation. This image was taken after $E$. coli cells were inoculated into the anode chamber with the potato extract, and the drop of potential across an external resistance reached the maximum and began to fall. Previous reports indicate that soluble compounds present in bacterial cultures can act as mediators in the transport of electrons from the cells to electrode surface (Wang et al., 2007; Zhang et al., 2007).

Corresponding polarisation curves were registered in the MFC fuelled by potato extract, with maximum power densities similar to that obtained when LB medium was used as the carbon source. The COD removal was in the range of $60.8 \pm 5.2 \%$ (medium value of three experiments) and the Coulombic efficiency, which was calculated based on the total substrate concentration, was $18.5 \pm 3.6 \%$ for a complete cycle (until voltage reached the maximum and fell). This result was consistent with the results obtained using different wastewaters, CE in the range of $6.7-8 \%$

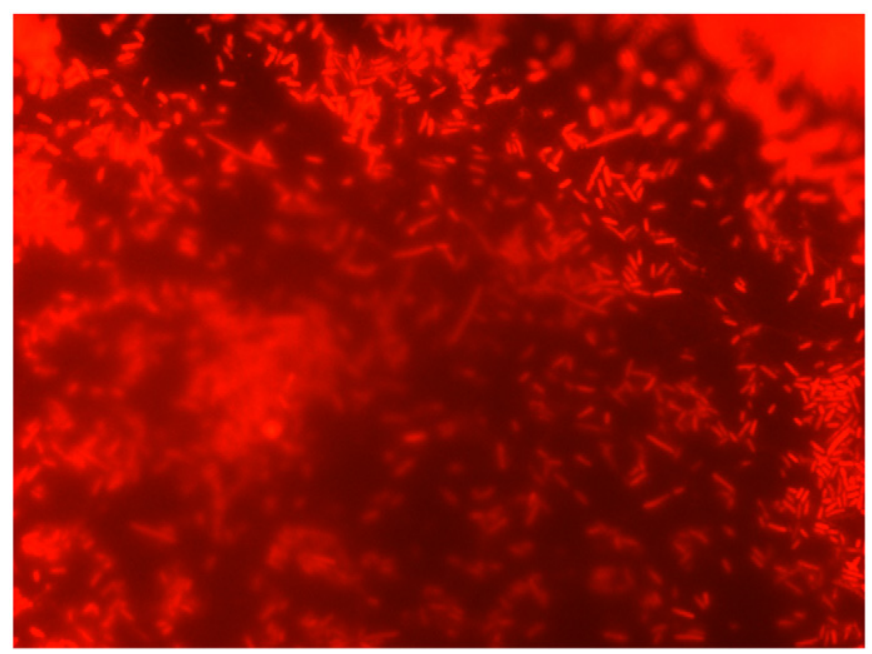

Fig. 5. Fluorescence micrograph of a Pt mesh electrode in the MFC using potato extract as the nutrient source, showing the $E$. coli biofilm at the time after the potential across the external resistance reached the maximum and began to drop.

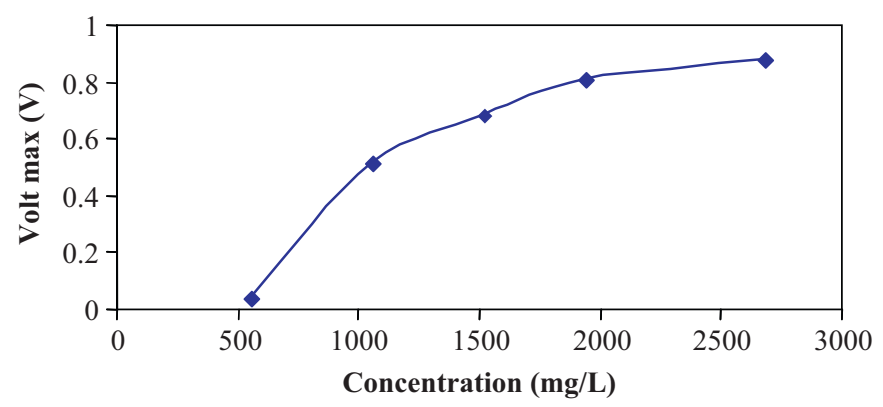

Fig. 6. Effect of initial potato extract concentration on voltage output.

were reported for starch processing wastewaters (Lu et al., 2009) and CE of $19.75 \%$ were reported for beer brewery wastewater (Wen et al., 2009). Higher recovery of electrons represents more effective oxidation of the organic energy sources and less loss of the cells contributing to production of electricity. Low CE is a general issue in MFCs with real wastewater. The main reason proposed for such problems is the presence of other available electron acceptors that electrons, thus lowering CE.

\subsection{Influence of substrate concentration on electricity generation}

The effect of potato extract concentration on electricity generation was determined by varying the initial concentration of potato extract in an M9 medium. Different experiments were conducted in which the anode chamber was loaded with an autoclaved glucosefree M9 medium plus potato extract over a concentration range of 552-2677 mg/L, and the voltage drop across the cell was monitored as a function of time, Fig. 6 shows the maximum drop of potential registered in each experiment. For the lower concentration of extract, there was negligible production of electricity. The output of the cell increased sharply when the amount of potato extract was doubled, and output increased further upon further increase in the amount of potato extract added until an initial concentration of $1933 \mathrm{mg} / \mathrm{L}$. For higher concentrations the maximum voltage drop was practically constant. As concentration of potato extract was increased the growth of bacteria increased with a consequent increase in the electricity production until a maximum was reached, which may be due to the maximum output of the metabolic enzymes at limiting substrate concentration. Maximum voltage reached was $0.85 \mathrm{~V}$ with a half-saturation constant $\left(K_{\mathrm{s}}\right)$ for the Michaelis-Menten equation of $1030 \mathrm{mg} / \mathrm{L}$.

\section{Conclusions}

The mediatorless microbial fuel cell (MFC) using E. coli was found to produce a maximum output of $502 \mathrm{~mW} \mathrm{~m}^{-2}$ when using platinised titanium mesh electrodes, which was approximately one order of magnitude greater than the maximum output achieved with Pt strip electrodes. This work also indicates that the nutrients present in potato extract, typical of effluents produced by the potato processing industry, can be used as an effective energy source for this type of MFC using E. coli as the biocatalyst. Similar values of potential and power density were obtained using the potato extract and the pure monosaccharide carbon source glucose. The COD removal efficiency observed shows that this MFC could also function as an alternative wastewater treatment unit in addition to biological electricity generation. CE was $18.5 \%$, in the range of that reported when wastewaters are used as the carbon source for MFCs. 


\section{Acknowledgements}

This work was supported by a Strategic Investment Fund grant from Sheffield Hallam University. The authors also acknowledge the technical support of Dr. David Greenfield.

\section{References}

Alferov, S., Coman, V., Gustavsson, T., Reshetilov, A., vonWachenfeldt, C., Hägerhäll, C., Gorton, L., 2009. Electrochimica Acta 54, 4979-4984.

APHA, 1998. Standard Methods for the Examination of Water and Wastewater, 19th ed. American Public Health Association/American Water Works Association/Water Environment Federation, Washington, DC, USA.

Bond, D.R., Lovely, D.R., 2003. Applied and Environmental Microbiology 69, 1548-1555.

Catal, T., Xu, S., Li, K., Bermek, H., Liu, H., 2008. Biosensors and Bioelectronics 24, 849-854.

Cercado-Quezada, B., Delia, M.L., Bergel, A., 2010. Bioresource Technology 101, 2748-2754.

Chaudhuri, S.K., Lovely, D.R., 2003. Nature Biotechnology 21, 1229-1232.

Gil, G.C., Chang, I.S., Kim, B.H., Kim, M., Jang, J.K., Park, H.S., Kim, H.J., 2003. Biosensors and Bioelectronics 18, 327-334.

Grzebyk, M., Pozniak, G., 2005. Separation and Purification Technology 41, 321-328.

Ieropoulos, I.A., Greenmana, J., Melhuish, C., Hart, J., 2005. Enzyme and Microbial Technology 37, 238-245.

Ito, Y., Yamazaki, S.I., Kano, K., Ikeda, T., 2002. Biosensors and Bioelectronics 17, 993-998.

Jiang, J., Zhao, Q., Zhang, J., Zhang, G., Lee, D.J., 2009. Bioresource Technology 100, 5808-5812.

Kim, H.J., Park, H.S., Hyun, M.S., Chang, I.S., Kim, M., Kim, B.H., 2002. Enzyme and Microbial Technology 30, 145-152.
Kim, J.R., Jung, S.H., Regan, J.M., Logan, B.E., 2007. Bioresource Technology 98 2568-2577.

Liu, Y., Dong, S., 2007. Electrochemistry Communications 9, 1423-1427.

Logan, B.E., Hamelers, B., Rozendal, R., Schröder, U., Keller, J., Freguia, S., Aelterman, P., Verstraete, W., Rabaey, K., 2006. Environmental Science and Technology 40, 5181-5192.

Lu, N., Zhou, S., Zhuang, L., Zhang, J., Ni, J., 2009. Biochemical Engineering Journal 43, 246-251.

Mano, N., Heller, A., 2003. Journal of the Electrochemical Society 150 , A1136-A1138.

Oh, S., Logan, B.E., 2005. Water Research 39, 4673-4682.

Park, D.H., Zeikus, J.G., 2000. Applied and Environmental Microbiology 66 1292-1297.

Park, D.H., Zeikus, J.G., 2003. Biotechnology and Bioengineering 81, 348-355.

Patil, S.A., Surakasi, V.P., Koul, S., Ijmulwar, S., Vivek, A., Shouche, Y.S., Kapadnis, B.P. 2009. Bioresource Technology 100, 5132-5139.

Prasad, D., Sivaram, T.K., Berchmans, S., Yegnaraman, V., 2006. Journal of Power Sources 160, 991-996.

Ramanavicius, A., Ramanaviciene, A., 2009. Fuel Cells 9, 25-36.

Ringeisen, B.R., Henderson, E., Wu, P.K., Pietron, J., Ray, R., Little, B., Biffinger, J.C. Jones-Meehan, J.M., 2006. Environmental Science and Technology 40 2629-2634.

Shantaram, A., Beyenal, H., Veluchamy, R.A., Lewandowski, Z., 2005. Environmental Science and Technology 39, 5037-5042.

Velasquez-Orta, S.B., Head, I.M., Curtis, T.P., Scott, K., 2011. Bioresource Technology 102, 5105-5112.

Wang, Y.F., Tsujimura, S., Cheng, S.S., Kano, K., 2007. Applied Microbiology and Biotechnology 76, 1439-1446.

Wen, Q., Wu, Y., Cao, D., Zhao, L., Sun, Q., 2009. Bioresource Technology 100 4171-4175.

You, S., Zhao, Q., Zhang, J., Jiang, J., Zhao, S., 2006. Journal of Power Sources 162 1409-1415.

Zhang, T., Cui, C., Chen, S., Yang, H., Shen, P., 2007. Electrochemistry Communications 10, 293-297. 